\title{
EXPRESSING OF NATIONAL AND CULTURAL IDENTITY IN ENGLISH AND RUSSIAN PROVERBS
}

\author{
T. Orlova, A. Kolosova, Y. Medvedev, S. Barov \\ RUDN University \\ Miklukho-Maklaya st., 6, Moscow, Russia, 117198
}

\begin{abstract}
The paper deals with the linguistic comparative structural and semantic analysis of English and Russian proverbs with the concept of 'happiness-unhappiness' that reflects national and cultural identity and the specificity of thinking of the English and Russian people. The aim of the paper is to explore and show similarities and differences in mentality and perception of the world by English and Russian people. This aim was achieved due to the study of the structural and semantic components and expressive-evaluative components of the proverbs. As a result of the study both common and specific meanings of the Russian and English proverbs were revealed in the languages under consideration. The object of the study is English and Russian proverbs associated with the binary concept of "happiness-unhappiness". During the analysis the basic meaning of the proverbs were revealed and systematized. The analysis of the phraseological meaning, lexical components, syntactic structures, expressive and emotive connotations, sound organization of English and Russian proverbs made it possible to identify the role of linguistic means in expressing the features of the mentality of the English and Russian peoples.
\end{abstract}

Key words: national and cultural identity; mentality; comparative structural and semantic analysis; stylistic devices; universality of human mind

\section{INTRODUCTION}

Modern linguistics constantly emphasizes the idea that language is not only a mean of thought expression, a mean of communication, but also a mean of reflecting the world around a man, and also expresses the mentality of people, their national character, customs and traditions. The most vividly national and cultural identity of the people is reflected in the phraseological body of a language, in particular - proverbs, which are short, well-defined sayings, containing teachings, advice, edification, judgments and moral appraisals.

Proverbs are an important means of cognition the national and cultural identity of folk's live, being a kind of clot of thought, "popular wisdom" of an ethnos. Proverbs show all the proverbial, intellectual-linguistic diversity and richness of languages with their inherent syntactic and analytical methods (see: [1]). Each ethnos in its own language reflects, in its own way, the world around it, depending on the characteristics of its life, different natural and climatic conditions, social structure, history, culture and traditions, etc. The difference between proverbs "in their imagery, local realities and concepts ... And everything in common is in their logical content, in the nature of the relations they transmit" [19]. We should add that the similarity in the meaning of proverbs is determined by the universal character of human thinking that is inherent in man, like homo 
sapiens. "The particular interest is the study of the proverbial conceptualization of the world, which makes it possible to establish general and various features in the comprehension of the world by two peoples ... to compare the mentality of peoples manifested in proverbs" [9].

The national-cultural component is contained in the structure of the phraseological meaning of the proverb. Especially visibly, it is revealed when the lexico-semantic components are compared in the structure of English and Russian proverbs. The need for comparative and semantic analysis of proverbs indicates E.V.Ivanova, who believes that "with regard to the study of a language picture of the world, particularly in terms of the comparative analysis of the conceptualization of the world in different languages, very illustrative material are phraseological units and paremias in particular proverbial fund of languages" [9].

By their structure, proverbs are complete sentences, and by semantics - an integral semantic unity that contains generalized information, for example, "a foreign side will not add mind", "the burden of your own choice is not felt", "own smoke will not tear your eyes", etc. Proverbs, like words and phraseology, are linguistic signs: they are systemic, that is, they are correlated in meaning, can have synonyms and antonyms, and have functional similarity. In their imagery, proverbs are close to folk-speaking and folk-poetic speech, folklore, especially this is characteristic of Russian proverbs: the presence of rhythmisation, consonance, rhyme. An important property of the proverb is imagery, expressiveness, evaluation, which arise from the metaphorical rethinking of its constituent components. This does not exclude in proverbs the semantic motivations of meaning, they possess both an internal form and a phraseological meaning. In the semantic structure of the proverb, it is possible to identify not only a denotation, but also a connotation (additional comprehension, expression, evaluation, emotivity).

We also should note that the proverbs were created during a long period of the historical life of a particular people. They show the language creativity of peoples. The well-known phraseologist V.N.Telia argues that "the typicality of the images underlying the meaning of phraseological units, as well as the inclusion of symbols or world standards in them, is the fruit of the collective representation of ... a linguistic and cultural community about some group experience" [25]. Proverbs include specific and familiar images, which in the process of use and rethinking acquire a deep generalization. In ethno-cultural metaphors there are ideas about a man, about his life, experiences, relationships - everything that determines the ethno-cultural existence of the people, his mentality.

The proverbs of many peoples reflect the national cultural information differently. These differences are revealed as a result of a comparison of the structure and semantics of these proverbs, revealing the similarities and differences in their conceptual proverbial fields.

\section{RESULTS}

It is known that national and ethnic proverbs are an integral part of the worldview of peoples, reflection of stereotypes, and the national and cultural identity. "Proverbs are succinct, memorable expressions that encapsulate the folk wisdom of a culture regarding ways of handling life's predicaments" [20]. 
In the parameological picture of the world the constants of national consciousness and culture are fixed. According to Wolfgang Mieder, proverbs, as an any folk genre "have for a long time been part of a verbal folk art giving durability to our understanding of the world. As part of the larger field of folklore they have played a major role in maintaining a basic framework for generations of people who have used them as common philosophical guides from childhood to old age" [17].

Proverbs and sayings as precedent texts, form ethnic picture of the world, reveal its national perception and thinking. Moreover, in the proverbs national values - the core of culture - are clearly reflected. As the well-known Dutch scholar Geert Hofstede claims, "Values are feelings with an added arrow indicating a plus and a minus side" [11].

People from different cultures have different values. Identifying cultural values through language of proverbs helps us to understand cultural differences, consequently, to understand each other. It is the language of proverbs through which the unconsciousness of values is revealed. 'Proverbs are in fact everywhere, and it is their ubiquity which has led scholars from many disciplines to study them from classical times to the modern age (see: [20]). A comparative study of languages and culture is an urgent task for modern scholars. "A nation's language... reflects its culture, psyche, and modes of thought" [4]. In this regard structural-semantic comparison of proverbs plays an important role because the centuries-old wisdom of people is reflected in proverbs as in a mirror. As one of the scholars mentioned, "language expresses cultural reality" [13]. The issue of analysis of proverbs was studied by a number of other foreign researchers.

The academic novelty of the paper is determined by the importance of the issue of interrelation of language and culture, the role of paremiology as a new philological science which demands an interdisciplinary approach of linguists, historians, scholars in culture studies. The binary concept 'happiness - unhappiness' is one of the key concepts both in the Russian and English languages.

A comparative study of proverbs as the basic unit of paremiology can be done from the angles of traditional linguistics, socio-linguistics; linguistic and cultural studies, cognitive linguistics and others. Our theoretical approach to the subject under consideration has been substantially influenced to a large degree by the works and semiotics studies of G. L. Permiakov who is considered 'one of the greatest theoretical paremiologists of the 20-th century" [19].

In order to provide the more complex and deep exploration of the issues mentioned above in our study we attempted to use different methodological approaches, including primarily traditional one - linguistic approach. All the proverbs were selected by continuous sampling method on the basis of using both Russian and English dictionaries (see: $[1 ; 3 ; 10 ; 13 ; 14 ; 22-25]$ ). Besides, functional-semantic method in selection of proverbs with similar meaning and comparative method to define similarity and differences of structure and semantics were applied.

That allowed us to "establish common and different features imperception of the world by the two peoples and reflection of this world in proverbs, compare the mentality of the people which can be seen in proverbs" [9]. 
Such a multiaspect approach of studying proverbs gives us both a broader picture about peculiarities of the peoples' mentality of the compared languages, and gives the idea of richness, expressiveness and vivid imagination of the languages, helps to reveal differences in semantic and stylistic volumes of proverbs.

For our analysis we selected the binary concept 'happiness-unhappiness' as the concept 'happiness' is considered to be one of the most important universal cultural values (see: [12]).

As a result of continuous sampling method and using both general and specialized Russian and English dictionaries, the following meanings in the semantic space of proverbs were selected:

1) misfortune never comes alone;

2) leave things as they are, do nothing if it can aggravate the situation;

3) misfortunes teach life, add experience, force to act;

4) not having tasted sorrow, one will know no happiness;

5) true friendship is tested in misfortune, misfortune is less when you are surrounded by friends;

6) we ourselves attract unhappiness;

7) worries and anxiety are destructive to human beings;

8) you can resolve other's trouble, but you cannot resolve your own ("you worry because of someone else's misfortune, but when you are in trouble, nobody does);

9) tears of sorrow do not help;

10) the trouble should be treated with humility and patience, there is no salvation when in woe.

The concept of "happiness" in the Russian language is expressed in such words as: dobro (goodness), udacha (luck), radost' (joy), nadezhda (hope), prazdnik (holiday). This technique testifies that such abstract notions as 'happiness-unhappiness' turn into concrete, simple, understandable, vital for common people words. Comparative structural and semantic analysis of the proverbs in the English and Russian languages, related to the concept "happiness-unhappiness" allowed to reveal the multisided attitude of the peoples towards this concept.

It is natural that every person wants to be happy. The issues of happiness and unhappiness had been actively discussed in Ancient Greek philosophy (Plato, Seneca and others). Due to the influence of Orthodox Church, Russians perceive happiness in the connection with suffering and unhappiness. Mind the following proverbs: 'Ne bylo by schast'ja, da neschast'e pomoglo' (If it weren't for bad luck have no luck at all); 'Gorja bojat'sja - schact'ja ne vidat' (No cross, no crown); 'Kto nuzhdy ne vedal, tot i schast'ja ne znaet' (Who didn't know the need will not know the happiness) and others.

It is should be mentioned that in the framework of Russian mentality the issue of moral right to be happy is very important. For example — 'Ne v den'gah schast'e' (Money doesn't bring/buy happiness).

Comparative analysis revealed that the concept 'happiness-unhappiness' is more expressed both in Russian and English proverbs through the meaning 'misfortune'. In Russian this meaning is transfered through the words beda, gore, liho, golod, greh, nuzhda, kruchina, gorest', pechal', hudo (misfortune, grief, hard times, hunger, sin, need, 
sorrow, woe, sadness). Some of the words belonging to this group of proverbs have archaic folk character: liho, hudo, gorest', kruchina, which can be translated into English with one word 'misfortunate'.

A significant group of proverbs which is widely presented in both English and Russian, reflects in our view, the universality of human thinking'. This group of proverbs expresses the following meanings: "misfortunes never come singly": It never (seldom) rains but it pours;Misfortunes(hardships) never come singly); An evil chance seldom comes alone; Misfortunes come on horse back, and go away on foot; One woe doth tread upon another's heels. These proverbs correspond to Russian proverbs: Prishla beda - otkryvaj vorota; Beda bedu naklikaet; Beda ne prihodit odna: sama idjot i druguju zovjot; Beda ne hodit odna; Odno gore idjot po pjatam drugogo; Beda edet, bedu vezjot, a tret'ja pogonjaet. Similar meanings of these proverbs in the English and Russian languages are due to the similarity of logical and figurative-associative relationships in the minds of the representatives of various lingvo-culturalethnic groups. This proverbial group refers to an earlier period of its origin, as evidenced by the old form "doth" (third person singular of the present tense of the verb to do). The most part of English proverbs of this group have national character, which is reflected in the system of their imagination, based on such methods as allegory (the use of natural phenomena for expressions of folk wisdom), personification which means attaching human features to such abstract concept as misfortune:Misfortunes "come on horse back", "go away on foot"; "tread upon another's heels", etc. English proverb uses expressive meaningful definition of "evil-chance", which enhances the meaning of inevitability, imminence of misfortune. Comparing English and Russian proverbs we can see similar methods of imagery and figures of speech in Russian proverbs: personification, allegory.

It should be mentioned that the oldest English proverb is completely identical to the Russian proverb Grief comes on the heels of another - Odno gore idet po pjatam drugogo. In this wау воth English and Russian proverbs have identical internal shape, figurative meaning and even the lexico-grammatical structure. In Russian proverbs the word "neschast'e" "unhappiness" is replaced by the synonymous words "beda" "trouble", "gore" — "woe" with national-colloquial usage.

Consider the next group of proverbs expressing the meaning: "leave everything as it is, or it will be worse": "Don't trouble trouble till trouble troubles you"; Let sleeping dogs lie; Let well alone; It is easier to raise the devil than to lay him and their Russian equivalents: Ne budi liho, poka liho spit (poka spit tiho); Ne drazni sobaku, ona i ne ukusit; Ne ishhi bedy, beda sama tebja syshhet; Hrani sebja ot bed, poka ih eshhjo net; Ne hleshhi kobylu, i ljagat' ne stanet; Ot greha podal'she. Using comparative analysis to this group of proverbs, which have more ancient origin, we can notice their similarities in structural and grammatical formation, their lexical content and figurative (imagery) meaning. This happens due to the fact that these proverbs contain edification, instruction that influence syntactic structure of the sentences which use verbs in form of imperative mood. Their resemblance is visible in an allegorical form of edification: "misfortune" is associated with person's everyday life, for example, zoonym "dog", which can bite (in English and Russian); with "devil" (in English only), zoonym "mare", which you shouldn't lash because it can lash out (in Russian). Thus, we can see that Russian, lexis 
is more linked with the realities of peasant's life and more archaic, for example — 'liho' (bad thing) in the meaning of 'neschast'e' (unhappiness, misfortune).

Let's look at the next group of proverbs, expressing the meaning: "misfortune, need teaches a lesson, add experience, mind, forces to act": Adversity is a great schoolmaster; Needs a must when the devil drives; Need makes the old wife trot; Hunger breaks stone walls. Here are the Russian equivalents: Bedy muchat, umu uchat (Woes torture teach your mind); Naterpish'sja gorja, nauchish'sja zhit' (Bear grief, learn to live); Nuzhda ostrit um (Need sharps mind); Chto muchit, to i uchit (What torment that teaches); Neschast'e — velikij uchitel' (Unhappiness is a great teacher); Nuzhda nauchit gorshki obzhigat' (Need will teach how to burn pots); Nuzhda vsemu nauchit (Need will teach everything); Gol' na vydumku hitra (Necessity is the mother of invention); Gore zastavit — byk solov'jom zapojot (Mount will force — Bull will sing like a nightingale); Nuzhda skachet, nuzhda pljashet, nuzhda pesenki pojot (Need jumps, dances, and sings songs).However, there are some unique Russian proverbs containing the opposite point of view: Schast'e uma pribavljaet, neschast'e — poslednij otymet (Happiness adds mind, unhappiness-takes last one); Inomu gore - uchen'e, inomu - muchen'e (Grief is a learning for one and a suffering for another) which testifies contradictive way of thinking of a Russian man.

Comparing English and Russian proverbs of this group, one may note that in the English proverbs in the meaning of "misfortune" may the words "adversity", "needs", "hunger" are used. And they make a person act. In the Russian language the proverbs with the words "misfortune" ("gore" — sorrow), "bedy" (destitutions), nuzhda (poverty), gol' (the beggars) teach, add mind, experience. Besides, they express the meaning "necessity to act".

One should note that English proverbs are rather expressive due to unusual behavior attributed to the subject, which often sounds ironic (Need makes the old wife trot), due to the use of allegories and hyperbola (Hunger breaks stone walls). Russian proverbs have a great variety at the expense of their lexico-syntactis structure. They are close to folklore due to using such stylistic devices as repetitions, syntactical parallelism, use of conjunctionless sentences, ellipsis, opposition and juxtaposition, rhyming endings, diminutive suffixes, etc.

The next group of English proverbs includes proverbs with the meaning "care and anxiety are harmful to a person, they can ruin the most viable and cheerful person": Care killed (will kill) a cat. In this proverb a person draws analogy between himself and an animal, it is allegorical in nature. Here are the Russians equivalents: Kruchina issushit v luchinu (Sorrow will dry up to splinter); Kruchina s nog sob'jot, nuzhda vovse zakljujot (Sorrow will knock off, need will peck to death); Bedy da pechali s nog skachali (Troubles and sadness knocked off); Gore chto bedy: borozdki prokladyvajut (Misfortunes like sorrows: lay furrows); Gore ne molodit (Sorrows don't make you younger); Gore odnogo tol'ko raka krasit (Mount makes red only a lobster; Morskih topit more, a suhoputnyh - gore (the seamen drown in the sea and the ground in sorrow). We discovered that this meaning is much wider and more dramatically presented in Russian proverbs, because the life of Russian peasants was more severe. 
Russian proverbs use folklore techniques: repetitions, unusual comparison and contrast, haveallegorical nature, associated with the phenomena of nature.

The proverbs about friendship can be divided in two subgroups. The first one expresses the meaning "misfortunes test true friendship". This meaning is widely represented much wider in English proverbs, as the British highly appreciate friendship, friendly relations: A friend in need is a friend indeed; Prosperity makes friends and adversity tries them; Calamity/Misfortune is man's true/best touchstone; A friend is never known till needed. They correspond to Russian proverbs: Drug poznajotsja v bede; Bez bedy druga ne uznaesh' (Without troubles will not know a friend); Neispytannyj drug nenadjozhen (Untested friend is unreliable).

The semantics of the other group of proverbs expresses the meaning "misfortune is less when you are surrounded by friends": Company in distress makes trouble less. This proverb corresponds to the Russian one: Na miru i smert' krasna. (Among close your people death can be beautiful). This proverb most clearly reflects the mentality of Russian people and their living conditions in a peasant community, called "mir". This proverb has one historicism "mir" which meant community and semantic archaism "krasna" in the old meaning "krasivyj" (beautiful). English proverbs about friendship in generic form pass code of honor. They are aphoristic, didactic, have neutral words, deprived of vivid imagery means, express mentality of representatives of more educated class. Comparing with the English proverbs, Russian proverbs are less expressive.

The patriotism of Englishmen, their attitude towards betrayal are brightly reflected in the proverb with the meaning "cowards or unworthy people leave their friends (common business or their country) in difficult times, in crisis or danger": Rats desert (leave) a sinking ship. This expression first appeared in the play by William Shakespeare "Tempest" in 1611 year. It reflects the popular belief that the ship rat feel catastrophe in advance. In Russian, there is a similar: Run like rats off a sinking ship which is the calque (word for word translation, loan translation) from the English.

The proverb Na obede — vse sosedi, prishla beda — oni proch' kak voda (At the dinner all are neighbors, in troubles they are away, like water) which has close meaning to the proverbs mentioned, is characterised by allegory, greater concretization of thought at the expense of more visible and meaningful juxtaposition and has a folklore nature.

There is a group of English proverbs which express the meaning "not having tasted sorrow will know no happiness": Who has never tasted bitter knows not what is sweet; He knows best what good is that has endured evil; Misfortunes tell us what fortune is. They correspond to the similar Russian proverbs; Gorest' ne prinjat' — sladkogo ne vidat'. (Not having (tasting) bitter, won't know sweet). The English proverb "Who has never tasted bitter knows not what is sweet"is an almost complete equivalent of the Russian proverb: Ne vkusiv (otvedav) gor'kogo, ne uznaesh' i sladkogo (Not having (tasting) bitter, won't know sweet), perhaps, due to their common source of origin. These proverbs in allegoric form has the biblical admonition that path to happiness goes through suffering. Both English and Russian proverbs have structural-semantic similarity, using generalized personal sentences.

Consider the English proverbs with the meaning "we attract unhappiness to us ourselves": The evils we bring on ourselves are the hardest to bear. This is a unique 
meaning which has no equivalents: in the Russian language. In Russian there is a proverb which is a bit similar to the English proverb and has the meaning "a person faces difficulties due to the actions that a person undertakes willingly": Ne znala baba gorja, tak kupila porosja (The woman's life was easy, until she made it busy — she bought herself a pig). These proverbs demonstrate differences in the mentality of both peoples.

Proverbs with the meaning "It easier to help someone else's trouble, than one's own are represented in Russian better, they have ironic tone and connected with the customs and beliefs of the Russians, in particular, divination on beans: Chuzhuju bedu rukami razvedu, a k svoej uma ne prilozhu (Other's problem will put away by a hand but can't make my mind about mine); Chuzhuju bedu na bobah razvedu, a k svoej uma ne prilozhu (Other's problem will solve by reading beans but can't make my mind about mine); Chuzhaja pechal' s uma svela, a po svoej potuzhit' nekomu (Other's grief took my mind and there is nobody to sorrow about mine).In English the same meaning is shown in the proverb: He is a fool that forget himself. As we can see, in the English language self-irony is expressed stronger, it is almost on the verge of ridicule.

In the semantics of English proverbs, British pragmatism is often indicated: Better the devil you know than the devil you don't//Known trouble is better than expected suspense. The Russian language has a very similar proverb: Iz dvuh zol vybiraj men'shee (Of two evils choose the lesser), which has almost complete English equivalent: Of two evils choose the least, as they have the common origin, dating back to the Latin proverb: "duobus malis minimum eligendum". Therefore, the common origin leads to the creation of full equivalents.

At the same time, there are unique meanings, which are an integral part of only Russian proverbs, they reflect the mentality of a man from peasant, folk environment. Such proverbs express submission to fate, patience, the inevitability of misfortune, for example: Gde bede byt', tam ejo ne minovat' (where trouble should be, there no one can avoid it); Pokoris' bede, i beda pokoritsja (obey troubles and troubles will obey); Nosi plat'e, ne skladyvaj, terpi gore, ne skazyvaj (wear a dress, do not store, endure grief do not speak about it); Ty ot gorja za reku, a ono uzh stoit na beregu (you run from grief over the river and it already stands on the shore); Ot sumy da ot tjur' my ne zarekajsja (don't count out a prison cell, a begging bowl may come as well); Bol'she gorja - blizhe k Bogu (More grief — closer to God). Such obedience to destiny, inevitability of disaster, piety is the result of the fact that the nature of Russian people was formed in difficult social and natural conditions, which differ from the European ones, so the Russian mentality is determined largely by its Orthodox dogma, the recognition of value of suffering.

In the ancient times Russian people believed in the folk omens, which is often was reflected in the number of proverbs, for example: Kukushka kukuet — gore veshhuet (Cuckoo calls - misfortune predicts or in whose yard the cuckoo calls, there will be misfortune). The cuckoo was considered as a bird that could foresee the future.

In the Russian proverbs which are more affected by psychology of representatives of folk environment the concept happiness-unhappiness is often associated with the word "food", for example: Pridjot beda - ne pojdjot na um i eda (Trouble comes will not mind food); U gor'koj bedy net sladkoj edy (Bitter grief has no sweet meals); 
Gore ne zaedajut, a zapit' mozhno (Grief can't be eaten but can be drunk); Luchshe hleb s vodoj, chem piry s bedoj (Better bread with water than feasts with misfortune). Russian proverbs have folklore character, their expressiveness is created by rhymes, lexical and syntactic juxtaposition using folk-spoken vocabulary.

The meaning "failures and success go after each other, changes for the better come after failures" is expressed in the following number of English proverbs: "There are a lot of them in English, for example: It is always darkest before the dawn; If there were no clouds we should not enjoy the Sun; A misty morning doesn't sign if a cloudy day; Every cloud has a silver lining; Nothing is bad as not to be good for something; It is a till wind that blows nobody good; It is a long lane that has no turning; Every dog has his day.

We found their Russian equivalents: Ne byvat' by schast'ju, da neschast'e pomoglo (It would not be happiness but unhappiness helped); Net huda bez dobra (every cloud has a silver lining); Posle grozy — vjodro, posle gorja — radost' (After the storm fine weather, after grief there will be joy); Chem noch' temnee, tem jarche zvjozdy (The night darker, the stars — brighter); Ne vsjo nenast'e, progljanet i krasnoe solnyshko (Bad weather is not forever, there will be Red Sun); Pridjot solnyshko i k nashim okoshechkam (The Sun will come to our little windows); Budet i na nashej ulice prazdnik (There will be a celebration on our street); Dovedjotsja i nam pesenku spet' (There willbe a celebration on our street and we will sing a song); Vsemu na svete prihodit konec (Everything on Earth comes to end); Schast'e i ne schast'e na odnih sanjah ezdjat (Happiness and unhappiness ride the same sleigh). As you can see, in the Russian proverbs happiness is compared with the phenomena of nature: for example: 'krasnoe solnyshko' (red sun), 'groza' (thunderstorm), 'vjodro' (sunny day), 'noch' (night), 'zvezdy' (stars) etc.

Expressiveness in the Russian proverbs is created due to the diminutive suffixes, as languages with developed affixation allow to express subtle semantic differences and expressiveness, which cannot be said about languages with poor affixing resources. Expressiveness of some Russian proverbs is created because of rich Russian wordformation by using a lot of diminutive-hypocoristic suffixes ("solnyshko", "okoshechko", "pesenka" and so on). The English proverbs of this group are also imagery and expressive. We can see close relationship between a man and nature. Abstract meaning of these proverbs can be seen through concrete manifestation of such natural phenomena as 'dawn', 'clouds', 'sun', 'wind', 'misty morning', 'cloudy day'. Such proverbs related to weather conditions, reflect the mentality of the British, living in a rainy, changeable climate, for whom sunny weather is associated with something good and cheerful.

English proverbs also reflect mentality of a man who is confident in the happy future. A large part of the English proverbs contains edification expressed by a simple two-part sentence. If we analyze the following selected group of English proverbs, expressing the meaning "one luck goes after another": Nothing succeeds like success; Luck goes in cycles; He dances well to whom fortune pipes. Let's see Russian equivalents: Gde schast'e povedjotsja, tam i petuh snesjotsja (Where happiness will settle a cock will lay eggs); Odna udacha idjot, druguju vedjot (One luck goes, another 
leads). We can notice that English proverbs are stylistically neutral and the imagery is created due to unusual lexical matching.

There is a group of English proverbs having the following meaning "a man must seek happiness, relying on his own forces": God helps those who help themselves; Every man is the architect of his own fortune; Fortune is good to him who knows how to make good use of it.

Here are the Russian equivalents: Vsjak svoemu schast'ju kuznec (Everyone is a blacksmith of his luck); Na Boga nadejsja, a sam ne ploshaj (Trust in God but be good yourself); Bog to Bog, da i sam bud' ne ploh (God is God but don't be bad yourself); Bogu molis', a k beregu grebis' (Pray to God but oar to the shore); Berezhjonogo i Bog berezhjot (God cares those who cares himself); Schast'e v vozduhe ne v'jotsja, a rukami dostajotsja (Happiness is not in the air, but can be caught by hands). The form of expression of thought in the English and Russian proverbs is different, but they both express optimism and reliance on one's own forces, characterizing both English and Russian people. However, almost all Russian proverbs mention God, reflecting godliness of Russian people. Besides, Russian proverbs have rhythmic structure through the use of similar sounding endings such as "molis'-grebis"”, "v'jotsja-dostajotsja", as well as the use of people's colloquial vocabulary.

The English proverbs "While there is life, there is hope; Never say die; If it were not for hope the heart would break" demonstrating the meaning "never leave hope and always hope for the best correspond to the Russian equivalents: Schast'e skoro pokidaet, a dobraja nadezhda — nikogda (Happiness soon leaves and good hope - never); Poka dyshu — nadejus' (As long as I breath I hope); Vek zhivi, vek nadejsja (Live your age and hope); Kolotis', bejsja, a vsjo nadejsja (Struggle and fight but hope); Nadezhda umiraet poslednej (Hope dies last). In spite of this there is a difference in the composition of English and Russian proverbs. English proverbs are didactic, have bookish character and structurally dissimilar. As far as Russian proverbs are concerned they are mostly compound sentences, they present structural juxtaposition and rhythmic organization.

The proverbs expressing the meaning that happiness is "easier to find than keep it". Compare the English and Russian proverbs: Fortune is easily found, but hard to be kept. Legko najti schast'e, a poterjat' i togo legche (Easily to find happiness and to lose it easier). These proverbs are transparent in their inner form and are partial equivalents, which argues the universality of human thinking.

We found another common meaning of English and Russian proverbs "you are happy when your children are happy". Compare: Happy is he that is happy in his children and its Russian analogue: Na chto klad, esli deti idut v lad (Why do you need a treasure, if your children go well). In spite of the fact that they have the similar meaning the English and Russian proverbs are different in their lexico-syntactic structure. English proverbs is a simple statement, its vocabulary is neutral. Russian proverb has a folklore character and an unusual juxtaposition and rhyming words.

Some Russian and English proverbs have no equivalents in the English and Russian languages: for example, the English proverb "He is happy that thinks himself so" in which the mentality of the British is vividly reflected has no equivalent in Russian, and vice versa: there are some Russian proverbs that have no equivalents in English. 
We can see it especially clear in the Russian proverbs in which happiness is understood as freedom: Schast'e — vol'naja ptashka, gde zahotela, tam i sela (Happiness is a free bird, it sits where it wants); Schast'e v oglobli ne vprjazhjosh' (you won't put happiness in shafts); Schast'e — ne batrak: za vihor ne pritjanesh' (Happiness is not a cottar you won't bring it with a cowlick); Schast'e ne dvorjanstvo, ne rodom vedjotsja (Happiness is not nobility, can't be inherited); Schast'e — ne kon': homuta ne nadenesh' (Happiness is not a horse you won't put a clamp on it).This understanding of happiness is typical for a Russian man and has a social nature. These proverbs indicate the freedom-loving character of Russian people and their desire to achieve happiness.

The concept of 'happiness-unhappiness' is one of the most important part in life of every person and people. We analyzed and compared only a part of British and Russian proverbs associated with the idea "happiness-unhappiness", but this range of proverbs enables us to get closer to understanding what mentality of English and Russian peoples is. The English and Russian proverbs of the concept "happiness-unhappiness" helped us to unveil these vital notions which are common to all linguistic and cultural ethnic groups despite the different language means.

Comparative structural and semantic analysis of the proverbs in the English and Russian languages, related to the binary concept "happiness-unhappiness" allowed to reveal the multisided attitude of the peoples towards this concept. On the one hand, there are some English and Russian proverbs that are basically identical and express the same meaning, which can be explained by both universal human nature and the same sources of origin (Bible), influenced Germanic and Slavic languages as well. On the other hand, there are proverbs in which cultural and national specifics are expressed.

The English proverbs are characterized by a certain didactic character, a special kind of understanding of happiness as a moral category, a greater strictness in the selection of lexical means and monotony of syntactic structures. However, many English proverbs use unusual lexical means (zoonyms, names of natural phenomena, allegory, imagery epithets, the technique of personification, rhyme, irony, sense of humor) that add them vividness, expressiveness and thus softening the didactic character. This is the mentality of a fairly educated Englishman living in other historical conditions.

In Russian proverbs, we found a similar understanding of the concept of "happinessunhappiness", particularly, in the understanding of the meaning "happiness" as a specific condition for a successful life. They contain both humor and vivid allegory and effervescent fun, joy in achieving happy life, however, the meaning of "bad luck", especially in Russian proverbs reveals the negative attitude to the bad living conditions (gore, beda, liho etc.). Russian proverbs also demonstrate the godliness of Russian people (reliance on God, the inevitability of fate), these are the personalities of the Russian mentality.

It should be mentioned that in Russian proverbs we meet extensive use of various folk means and in particular, sound (rhyme, rhythm, alliteration), semantic and stylistic techniques (epithets, similes, metaphors, impersonation, irony, metaphor), syntactic means (concurrency syntactic structures, repetitions, graduation) and lexical resources (historism, archaism, people's collocations, emotional and expressive colored vocabulary etc.). Using of folklore methods suggests that a Russian man is a man from peasant's environment, who has such characteristics as poetry, humor, observance and even 
superstition. Thus, structural-semantic analysis of English and Russian proverbs revealed their figurative and linguistic specificity and national-cultural identity.

Russian proverbs are characterized by the use or partial rhyme, sound repetitions, which create melodiousness, both internal and external harmony, syntactic similar constructions (parallelism), comparisons, allegory, methods of folklore, poetry of Russian character, which is also a distinctive feature of nature of Russian mentality. The national identity of English and Russian proverbs is reflected due to special conditions of climatic, material, socio-economic and cultural life of the peoples. The materials and results of the research can be applied in teaching and translation activity as well as in intercultural communication.

\title{
CONCLUSIONS
}

Comparative structural and semantic analysis of English and Russian proverbs, showed that among them one can identify equivalent in meaning proverbs, as well as analogues, in which the features of a national character are vividly displayed. However, English proverbs are more distinctive in their didactic, edifying character, they are more specific, they often use correlative, adversative and motivational proposals. They use more neutral vocabulary. Emotivity and imagery is created through the inclusion of unusual lexical components (zoonyms, antonyms, somatisms, etc.).

Russian proverbs, despite being also edifying, are more expressive. They include folk-spoken, often archaic vocabulary, use diminutive affectionate suffixes, more often use sound repetitions and rhymes that serve to actualize their meaning and contribute to their memorization. They also widely use comparative and adversarial constructions, as well as syntactic parallelism. In general, they are close to folklore. Most of the English proverbs, in their structure and didactic orientation, are aphoristic, they contain a more neutral vocabulary. This shows that in English proverbs the mentality of an educated person is represented, whereas in Russian proverbs the image of a man's thoughts from a people's, peasant environment that carries in him not a high culture, but rather humanity and kindness, not avoiding of some cunning, "acumen".

To sum up: the analysis of English and Russian proverbs of the conceptual paradigm "happiness-misfortune" made it possible to reveal the basic life values of the Russian people - compassion, mercy, deep love of humanity, mutual aid, natural naivety and even some simplicity, in general, kindness, while English proverbs reflect quite different features - stiffness and at the same time some freethinking, combined with closeness and lack of dreaminess, an overly harsh view of life, in general, the ultimate pragmatism.

\author{
(C) T. Orlova, A. Kolosova, Y. Medvedev, S. Barov \\ Дата поступления: 24.02.2018 \\ Дата приема в печать: 24.03.2018
}

\section{REFERENCES}

1. Ayto, J. (2010). Oxford Dictionary of English Idioms (Oxford Quick Reference) 3rd Edition Oxford University Press.

2. Cluski, J. (1971). A comparative book of English, French, German, Italian, Spanish and Russian proverbs with a Latin appendix/ comp. and ed. by Jerzy Cluski - Amsterdam; London, New York: Elsevier, XXXVIII. 
3. Dal', V.I. (20042007). Tolkovyj slovar' zhivogo velikorusskogo jazyka. Sovremennoe napisanie. 4 vol. M.: AST, Astrel'.

4. Deutscher, G. Through the Language Glass: Why the World Looks Different in Other Languages, 2011, p. 9, 320 p.

5. Doyle, Charles Clay The dictionary of modern proverbs / Comp. by Charles Clay Doyle, Wolfgang Mieder, and Fred R. Shapiro - New Haven; London: Yale university press, cop. 2012 - XIV, $294 \mathrm{p}$.

6. Dubrovskaya, O.G. Russian and English proverbs as culturological units. Tyumen, 2002, p. 148.

7. Flavell Linda and Roger Dictionary of proverbs: and their origins / Linda and Roger Flavell. London: Kyle Cathie, 2008, 280 p.

8. Honeck, R.P. A proverb in mind: The cognitive science of proverbial wit and wisdom. Mahwah, NJ: Erlbaum, 1997, 318 p.

9. Ivanova, E.V. Mir v anglijskikh i russkikh poslovitsakh: Uchebnoe posobie [World in English and Russian proverbs: Textbook]. SPb.: ed. St. Petersburg State University, 2006, p. 3, 280 p.

10. Jackson, A.L. The dynamics ofproverbial sayings: discover the connections within / by Lorenzo A. Jackson. Great Britain: Lorenzo A. Jackson, 2011, 360 p.

11. Hofstede, Geert H. Cultures and Organizations: Software of the Mind: Inter cultural Cooperation and its importance for Survival (by Geert, Hofstede, Gert Jan Hofstede and Michael Minkov. 3rd ed. N.Y: McGraw-Hill, 2010, p.61, 576 p.

12. Kotova, M. Russko-slavianskii slovar' poslovits s angliiskimi sootvetstviiami [Russian-Slavic dictionary of proverbs with their English equivalents]. Saint Petersburg, University Publ., 2000, p. 22,360 p.

13. Kramsch, C. Language and Culture (Oxford Introductions to Language Study). Oxford: Oxford University Press, 1998, p. 3, 134 p.

14. Manser, Martin H. The Facts on File dictionary of proverbs / Manser: accociate editor, Rosalind Fegusson. Martin H. Manser NewYork; [Great Britain]: Favts on File, 2002, 440 p.

15. Margulis, A., \& Kholodnaya, A. Russian-English Dictionary of Proverbs and Sayings North Carolina: McFarland, 2008, 495 p.

16. Mieder, W. Proverbs. Handbook. Westport \& Connecticut \& London, Greenwood Publishing Group, 2004 (reprinted 2011), 304 p.

17. Mieder, W. Tradition and Innovation in Folk Literature. Routledge, 2015, p. 1, 304 p.

18. Friedman, M., Chen, H.-Ch., \& Jyotsna Vaid, Jy. Proverb preferences across cultures: Dialecticality or poeticality? Psychonomic Bulletin \& Review, 2006, 13 (2), pp. 353-359.

19. Permjakov, G.L. Osnovy strukturnoj pareomiologii. M.: Nauka, 1988, p. 16, 236 p.

20. "Proverbs Speak Louder Than Words": Folk Wisdom in Art, Culture, Folklore, History, Literature and Mass Media (2008). N.Y.: Peter Lang Inc., International Academic Publishers, 2008, pp. 9-10, 357 p.

21. Sergeeva, A.V. Russkie: stereotipy povedenija, tradicii, mental'nost'. M.: Flinta: Nauka, 2010, $320 \mathrm{p}$.

22. Shatskaya, E.Y. Tematicheskij slovar' russkikh i anglijskikh poslovits i pogovorok [Thematic Dictionary of Russian and English proverbs and sayings]. Publisher "Pero", Moscow, 2013, $157 \mathrm{p}$.

23. Slovar' upotrebitel'nykh poslovits [Glossary of commonly used proverbs] / M.V. Bukovskaya, S.I. Vyal'tseva, Z.I. Dubyanskaya i dr. Moscow, Russian language, 1990, 234 p.

24. Speake, J. The Oxford Dictionary of Proverbs. Oxford University Press, 2015, 416 p.

25. Telia, V.N. Russian phraseology: semantic, pragmatic and linguistic-cultural aspects. M., 1996, p. 249.

26. Zhukov, V.P. Slovar' russkikh poslovits i pogovorok [Dictionary Russian proverbs and sayings]. M., 1990, $537 \mathrm{p}$. 


\title{
ВЫРАЖЕНИЕ НАЦИОНАЛЬНОЙ И КУЛЬТУРНОЙ ИДЕНТИЧНОСТИ В РУССКИХ И АНГЛИЙСКИХ ПОСЛОВИЦАХ
}

\author{
Т.Г. Орлова, А.А. Колосова, \\ Ю.С. Медведев, С.А. Баров \\ Российский университета дружбы народов \\ ул. Миклухо-Маклая, 6, Москва, Россия, 117198
}

\begin{abstract}
В статье проводится сопоставительный структурно-семантический анализ английских и русских пословиц, выражающих идею «счастье-несчастье» и отражающих национально-культурную самобытность и специфику мышления английского и русского народов. Цель статьи - описать и показать сходство и различия в менталитете и восприятии мира носителями английского и русского языков. Эта цель была достигнута благодаря изучению структурных и семантических особенностей и выразительно-оценочных компонентов пословиц. В результате исследования на материале указанных языков были выявлены общие и специфические свойства русских и английских пословиц. Объектом исследования являются английские и русские пословицы, связанные с бинарной концепцией «счастье- - несчастье». Во время анализа был выявлен и систематизирован основной смысл пословиц. Анализ фразеологического значения, лексических компонентов, синтаксической структуры, выразительных и эмоциональных свойств, коннотаций, организации английских и русских пословиц позволили определить роль лингвистических средств в выражении особенностей менталитета носителей английского и русского языков.
\end{abstract}

Ключевые слова: национальная и культурная идентичность; менталитет; сравнительный структурный и семантический анализ; стилистические свойства пословиц; универсальность человеческого разума

\section{For citation:}

Orlova T., Kolosova A., Medvedev Y. \& Barov S. (2018). Expressing of national and cultural identity in English and Russian proverbs. RUDN Journal of Language Studies, Semiotics and Semantics, 9 (2), 320-334. doi: 10.22363/2313-2299-2018-9-2-320-334.

\section{Сведения об авторах:}

Орлова Татьяна Геннадьевна, кандидат филологических наук, доцент кафедры иностранных языков факультета гуманитарных и социальных наук РУДН; научные интересы: сравнительное языкознание; e-mail: orlova_tg@mail.ru

Колосова Алевтина Александровна, кандидат исторических наук, доцент кафедры межкультурной коммуникации филологического факультета РУДН; научные интересы: прикладная лингвистика, межкультурная коммуникация; e-mail: kolosova_aa@mail.ru

Медведев Юрий Сергеевич, кандидат исторических наук, доцент кафедры иностранных языков факультета гуманитарных и социальных наук РУДН; научные интересы: лингвокульторология; e-mail: medvedev_ys@mail.ru

Баров Сергей Андреевич, кандидат политических наук, доцент кафедры иностранных языков факультета гуманитарных и социальных наук РУДН; научные интересы: контрастивная лингвистика, лингвокульторология; e-mail: barov_sa@pfur.ru 


\section{Bio Note:}

Orlova Tatiana Gennadievna, Candidate of Philology, Associate Professor, the Department of Foreign Languages, Faculty of Humanities and Social Sciences, PFUR; scientific interests: comparative linguistics; e-mail: orlova_tg@mail.ru

Kolosova Alevtina Aleksandrovna, Candidate of Historical Sciences, Associate Professor, the Department of Intercultural Communication, Faculty of Philology, PFUR; scientific interests: applied linguistics, intercultural communication; e-mail: kolosova_aa@mail.ru

Medvedev Yuri Sergeevich, Candidate of Historical Sciences, Associate Professor, the Department of Foreign Languages, Faculty of Humanities and Social Sciences, PFUR; scientific interests: lingvocultorology; e-mail: medvedev_ys@mail.ru

Barov Sergey Andreevich, Candidate of Political Sciences, Associate Professor, the Department of Foreign Languages, Faculty of Humanities and Social Sciences, PFUR; scientific interests: contrastive linguistics, linguocultorology; e-mail: barov_sa@pfur.ru 